\title{
Food restriction but not fish oil increases fertility in hens: role of RARRES2?
}

\author{
Namya Mellouk 1,2,3,4 , Christelle Ramé1,2,3,4, Joël Delaveau ${ }^{5}$, Christophe Rat ${ }^{5}$, \\ Maxime Marchand ${ }^{5}$, Frédéric Mercerand ${ }^{5}$, Angélique Travel ${ }^{6}$, Aurélien Brionne ${ }^{7}$, \\ Pascal Chartrin ${ }^{7}$, Linlin Ma ${ }^{1,2,3,4}$, Pascal Froment ${ }^{1,2,3,4}$ and Joëlle Dupont ${ }^{1,2,3,4}$ \\ ${ }^{1}$ INRA UMR85 Physiologie de la Reproduction et des Comportements, Nouzilly, France, ${ }^{2}$ CNRS UMR7247 \\ Physiologie de la Reproduction et des Comportements, Nouzilly, France, ${ }^{3}$ Université François Rabelais de Tours, \\ Tours, France, ${ }^{4}$ IFCE, Nouzilly, France, ${ }^{5}$ INRA - Unité Expérimentale du Pôle d'Expérimentation Avicole de Tours

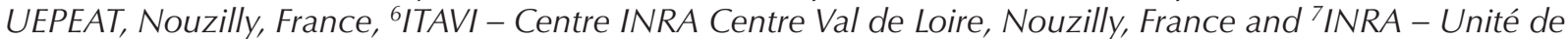 \\ Recherches Avicoles, Nouzilly, France
}

Correspondence should be addressed to D Joëlle; Email: joelle.dupont@inra.fr

\begin{abstract}
Overfed hens selected for their rapid growth become fatter and develop reproductive disorders. Herein, we aimed to demonstrate that food restriction leading to a weight reduction and/or a supplementation with fish oil may be effective in preventing reproductive disorders through the regulation of adipokine expression in broiler hens. This study included four groups of food restricted (Rt) or ad libitum hens (Ad, feeding at a rate 1.7 times greater than Rt hens) supplemented or unsupplemented with fish oil (1\%). The Rt diet significantly increased plasma chemerin (RARRES2) levels during the laying period, delayed sexual maturity by one week and improved egg quality and fertility. These effects were associated with higher progesterone production in response to IGF1 (or LH) in cultured granulosa cells and in vivo egg yolk, as compared with Ad hens. Fish oil supplementation had similar effects to the Rt diet on progesterone $(P<0.05)$, but without any effect on fertility. Using RT-PCR, we found that RARRES2 levels were lower in theca cells of Rt hens and NAMPT levels were increased by the fish oil supplementation. A significant positive correlation between RARRES2 expression in granulosa cells and the weight of F1 preovulatory follicle was observed, as well as a negative correlation of plasma RARRES2 levels with hatchability. Thus, food restriction but not fish oil supplementation improved fertility, and this was associated with variations in RARRES2 plasma and ovarian expression in hens.

Reproduction (2018) 155 321-331
\end{abstract}

\section{Introduction}

In domestic animals including poultry, nutrition has profound effects on reproductive functions including folliculogenesis, fertilisation and early embryonic development (Sirotkin \& Grossmann 2015, van Emous et al. 2015). Reproduction is an energetically costly process. There is a strong association between metabolic disorders and infertility, but some of the mechanisms mediating the influence of metabolism and nutrition on fertility are currently unclear. In chicken, standard broiler breeders have been submitted to high selection pressure for growth and feed efficiency, resulting in metabolic disorders and reproductive dysfunction (Chen et al. 2006, Decuypere et al. 2010). Overfeeding during reproductive development is associated with disruptions in steroid production, leading to the formation of excessive numbers of ovarian yellow follicles arranged in multiple hierarchies and, in turn, increased production of unsettable eggs (Hocking et al. 1989, Heck et al. 2004, Decuypere et al. 2010). Hocking et al. (1993) also showed a relationship between hen weight and sexual maturity and with the number of large ovarian follicles. The maintenance of reproductive performance (laying and fertility) can only be ensured if a strict food restriction is applied at a very early age (2-3 weeks after hatching). However, it appears that the application of this restriction has side effects on animal welfare manifested in changes in social and feeding behaviour (Savory \& Maros 1993). Moreover, the functional mechanism of the crosstalk between nutrition and reproductive regulation is still not fully explained.

Metabolites, nutrients and metabolic hormones are considered as potential mediators affecting reproduction. Among the metabolic hormones, the adipokine family are produced mainly by white adipose tissue. They include leptin (LEP), visfatin (NAMPT), chemerin (RARRES2) and adiponectin (ADIPOQ) and have been associated with fattening in mammals (Haider et al. 2006, Chang et al. 2016, de Luis et al. 2017). Furthermore, it is well known that normal 
levels of adipokines are fundamental to maintaining the integrity of the hypothalamus gonadotrope axis, regular ovulatory processes, successful embryo implantation and physiological pregnancy (Malik et al. 2001, Kasher-Meron et al. 2014, Maillard et al. 2017). They are also particularly important in interactions between metabolism and reproduction in mammals (Farshchian et al. 2014, Chen et al. 2015, Kort et al. 2015). In chicken, the presence of LEP is controversial (Taouis et al. 1998, Pitel et al. 2010). However, it has been clearly demonstrated that two of these three adipokines (ADIPOQ and NAMPT) play a critical role in the regulation of carbohydrate and lipid metabolism (Yan et al. 2013, Li et al. 2017), as well as in reproductive functions in poultry (Diot et al. 2015a,b). The plasma concentration of ADIPOQ is inversely correlated with adiposity and blood glucose levels in chickens (Hendricks et al. 2009) and decreases during the laying period in turkeys (Diot et al. 2015b). In addition, ADIPOQ and its receptors, as well as NAMPT, are expressed in ovarian cells (Chabrolle et al. 2007, Diot et al. 2015a). In contrast to mammals, NAMPT is more of a myokine than an adipokine (Krzysik-Walker et al. 2008). Furthermore, we have recently shown that NAMPT is capable of inhibiting the production of progesterone in hen primary granulosa cells (Diot et al. 2015a). While NAMPT and ADIPOQ, along with its two main receptors ADIPOR1 and ADIPOR2 have largely been described, very few data about chicken RARRES2 and RARRES2 receptors (CMKLR1, CCRL2 and GPR1) are available.

In mammals, adipokine plasma levels are upregulated by fish oil, which could potentially improve fertility in addition to its beneficial effects on metabolic disorders (Flachs et al. 2006, Wathes et al. 2007). Thus, fish oil could be a good nutritional supplement for broiler breeder hens with reproductive impairment. However, to our knowledge, the influence of adipokine levels in plasma and ovarian cells on reproductive parameters (laying and fertility) in hens has not been investigated in different nutritional states. In this present study, we hypothesise that circulating and/or ovarian expression levels of adipokines could be modulated by food restriction and/or fish oil supplementation and could be associated with improved egg production and quality, and consequently fertility parameters. Thus, we investigated the effects of food restriction and fish oil supplementation on egg production and quality, ovarian steroidogenesis and fertility parameters in broiler hen breeders. We also aimed to characterise the relationship of these different parameters with circulating and ovarian expression levels of adipokines.

\section{Materials and methods}

\section{Ethical issues}

An ethics committee 'Comité d'Ethique en Expérimentation Animale Val de Loire' (CEEA VdL №19) protocol registered

Reproduction (2018) 155 321-331 under ref. $n^{\circ} 01607.02$ approved all experimental studies, which were consistent with the guidelines provided by the French Council for Animal Care.

\section{Animals}

Three hundred and twenty female broiler breeder chicks (Cobb 500) from Hendrix Genetics (Saint Laurent de la Plaine, France) were studied from hatching to 39 weeks old. On the day of hatching, animals were distributed into homogeneous groups of 10, and kept in 32 pens of $3 \mathrm{~m}^{2}$ with thermostatically controlled air inlets and a dynamic cross-ventilation system. Each pen was equipped with a hanging feeder, drip nipples and $5 \mathrm{~kg}$ of fresh wood shavings as litter. Animals were reared at 'Pôle Expérimental Avicole de Tours' (INRA, Nouzilly, France) under conventional breeding conditions (Cobb-Vantress 2008): $24 \mathrm{~h}$ of light on arrival, day length being reduced to approximately $8 \mathrm{~h}$ at two days of age, then kept constant until the age of photostimulation (21st week). From 21 weeks of age, there was a gradual increase in exposure to light up to $15 \mathrm{~h}$ per day at 25 weeks. The animals were maintained under this light regime until the end of the experiment.

\section{Diets}

From day one to four weeks of age, female breeder chicks received an ad libitum diet (free access to food) named starting diet. At week 4, animals were divided into two groups. The first group $(n=160)$ received a growth restriction diet according to Hendrix Genetics recommendation, while the second group $(n=160)$ named 'ad libitum' daily received the same diet but in an amount 1.7 times greater than that given to the restricted animals. From nine to 39 weeks of age, these two groups were subdivided into two groups, supplemented or unsupplemented with fish oil (group RNS: restricted unsupplemented, group ANS: ad libitum unsupplemented, group RS: restricted supplemented, group AS: ad libitum supplemented). During this period, the four groups of animals received three different diets (growing, pre-lay and laying). The supplement was a protected encapsulated fish oil OMG750 provided by Kemin (Nantes, France). It is composed of $77 \%$ of refined fish oil and $23 \%$ gelatin (the capsule). The supplement was manually mixed into the diet at $1 \%$ of the total diet. The composition and the nutrient contents of the diet and the fatty acids composition of the supplement $(\mathrm{mg} / \mathrm{kg}$ ) are shown in Supplementary Table 1A and $B$, respectively (see section on supplementary data given at the end of this article). The fatty acid concentration (mg/ $\mathrm{kg}$ ) in the different diets and in eggs yolk are represented in Supplementary Table 1C and D respectively. The weight and the fattening of animals were measured every three weeks using an automated balance and ultrasound, respectively (Supplementary Table 2A). The feed conversion by the animals was calculated as the ratio between the weight gain (6-9, 9-18, 18-21 weeks) or number of eggs laid (23-39 weeks) and the feed intake during the period (Supplementary Table 2B). Plasma triglyceride, phospholipid, cholesterol, glucose and insulin concentrations were obtained using enzymatic assays at 21,27, 32 and 39 weeks, as previously described by Diot and coworkers (2015b) (Supplementary Table 2C).

www.reproduction-online.org 


\section{Measurement of egg production and quality}

From the 23rd week the eggs from each pen were collected, counted and weighed using a balance (OHauss, Pionner) twice a day. The weight of the albumen, the egg yolk and the dehydrated shell were also measured separately using a balance (Ohauss, Pionner). The numbers of normal, soft, double (eggs with two egg yolks) and broken eggs were determined. At the 25th week, the length and the width of the eggs laid by the four groups of animals were measured using a digital calliper (Mitutoyo, CD-20DCX), and their static stiffness (Sd) and their tensile strength $(F)$ were evaluated using an Instron instrument (Instron, UK527). The elastic modulus (Young's modulus expressed in $\mathrm{N} / \mathrm{mm}^{2}$ ) and toughness (N/ $\mathrm{mm}^{3}=2$ ) of the shell were estimated according to the formulae developed by Bain (Sauveur 1988, Bain 1990, Guesdon et al. 2006). Micro-cracked eggs were detected using an Acoustic Egg Tester (Coucke et al. 1999, Dunn et al. 2005).

\section{Determination of number and weight of follicles}

At 39 weeks old, 13 hens per group were selected randomly and their preovulatory follicles were collected, hierarchically defined and weighed.

\section{Fertility parameters}

The semen of 65 cocks (Cobb500) was collected and pooled to form a single sample. The hens were artificially inseminated with $2 \times 10^{8}$ spermatozoa from the pool at the 27 th and 32 nd week and eggs were collected and counted daily for two weeks following the artificial insemination and incubated every seven days (Supplementary Table 3A). The number of unfertilised eggs, and early (EEM) and late (LEM) embryonic mortality was evaluated by breaking eggs and candling on the 7th (EEM) and 14th day of incubation (LEM) (Supplementary Table 3B and C). The different percentages (EEM, LEM, hatchability of eggs set, fertility and hatchability of fertile eggs) were measured using the following formulae:

$\% \mathrm{EEM}=$ number of EEM /

(number of incubated eggs - unfertilised eggs)*100,

$\%$ LEM = number of LEM / (number of incubated eggs -

(unfertilised eggs + number of EEM)*100,

$\%$ Hatchability of incubated eggs =

(number of hatched chicks / number of incubated eggs)*100,

$\%$ Fertility $=\left(\begin{array}{l}\text { number of fertile eggs after } 14 \text { days of } \\ \text { incubation } / \text { number of incubated eggs }\end{array}\right) * 100$,

$\%$ Hatchability of incubated eggs $=$ $\left(\begin{array}{l}\text { number of hatched chicks / number of } \\ \text { fertile eggs after } 14 \text { days of incubation }\end{array}\right) * 100$.

\section{Measurement of progesterone, oestradiol, androstenedione and testosterone deposition in egg yolk}

Steroids from six egg yolks per group were extracted with diethyl ether after intense agitation and centrifugation. The steroid-containing diethyl ether phase was decanted after freezing the tubes in nitrogen for $10 \mathrm{~s}$. The organic solvents were then evaporated and the extracts taken up in phosphate buffer. Steroid hormones (progesterone, oestradiol, testosterone and androstenedione) were then measured in the extracts using ELISA assays. For progesterone, the ELISA assay was performed as described by Canepa et al. (2008). The sensitivity of the assay was $0.4 \mathrm{ng} / \mathrm{mL}$. Oestradiol and testosterone concentrations were determined using commercial ELISA assays from Cayman Chemicals and the sensitivity of these assays was $0.01 \mathrm{ng} / \mathrm{mL}$. Androstenedione levels were analysed using an ELISA assay from Abcam and the sensitivity of the assay was $0.01 \mathrm{ng} / \mathrm{mL}$. The intra-assay and inter-assay coefficients of variation (CV) for each assay averaged $<10 \%$.

\section{In vitro culture of hen granulosa cells}

Granulosa cells from preovulatory F1 follicles of three hens per group (25-26th week, selected randomly) were collected and dispersed in $0.3 \%$ collagenase type $A$ (Roche) in F12 medium containing $5 \%$ foetal bovine serum (FBS), at $37^{\circ} \mathrm{C}$. Cells were pelleted by centrifugation, washed twice with fresh medium and counted in a haemocytometer. The viability of F1 granulosa cells estimated by Trypan Blue exclusion was about $95 \%$. Cells were cultured in a medium composed of DMEM supplemented with $100 \mathrm{U} / \mathrm{mL}$ penicillin, $100 \mathrm{mg} / \mathrm{L}$ streptomycin, $3 \mathrm{mmol} / \mathrm{L}$ L-glutamine and 5\% FBS. The cells were initially cultured for $24 \mathrm{~h}$ with no treatment. After overnight serum deprivation, cells were stimulated with IGF1 $\left(10^{-8} \mathrm{M}\right)$ or $\mathrm{LH}\left(10^{-8} \mathrm{M}\right)$ or left untreated for $48 \mathrm{~h}$. All cultures were maintained under a water-saturated atmosphere of $95 \%$ air $/ 5 \% \mathrm{CO}_{2}$ at $37^{\circ} \mathrm{C}$ (Chabrolle et al. 2007, Diot et al. 2015a).

\section{In vitro measurement of progesterone secretion by granulosa cells}

The concentration of progesterone secreted into the medium by granulosa cells under the various conditions was determined according to an ELISA protocol described by Canepa et al. (2008). The sensitivity of the kits was $0.4 \mathrm{ng} / \mathrm{mL}$. The intra- and inter-assay coefficients of variation were $<10 \%$ and $<4.3 \%$ respectively. This experiment was carried out using four replicates of three hens for all groups studied, and the results are presented according to the average of these twelve experiments.

\section{Adipokine assays}

Plasma concentrations of adipokines were obtained using chicken-specific kits (E12V0003: sensitivity $1 \mathrm{ng} / \mathrm{mL}$, E12A0125: sensitivity $0.1 \mathrm{ng} / \mathrm{mL}$, and E12C0104: sensitivity $1 \mathrm{ng} / \mathrm{mL}$, respectively for NAMPT, ADIPOQ and RARRES2; Holzel Diagnostika, Koln, Germany). The measurements were 
carried out according to the manufacturer's protocol with an intra-assay coefficient of variation $<6 \%$. The absorbance was measured at $450 \mathrm{~nm}$ and concentrations were estimated referring to a standard reference range.

\section{Measurement of the expression of adipokines and their receptors in granulosa and theca cells}

Total RNA from granulosa and theca cells of preovulatory follicle 1 (F1) and 3 (F3) of eight animals from each group was extracted by homogenisation in TRIzol reagent using an ULTRA-TURRAX instrument and purified using a DNAfree kit according to the manufacturer's recommendations (Invitrogen by Life Technologies). cDNA was generated by reverse transcription (RT) of total RNA $(1 \mu \mathrm{g})$, incubating for one hour at $37^{\circ} \mathrm{C}$ in a mixture containing: $0.5 \mathrm{mM}$ each deoxyribonucleotide triphosphate (dATP, dGTP, dCTP, DTTP) $2 \mathrm{M}$ of RT buffer, $15 \mu \mathrm{g} / \mu \mathrm{L}$ of oligodT, $0.125 \mathrm{U}$ of ribonuclease inhibitor and 0.05 U MMLV (Moloney murine leukaemia virus reverse transcriptase). Real-time PCR was performed using the MyiQ Cycle device (Bio-Rad), in a mixture of SYBR Green Supermix 1X reagent (Bio-Rad), $250 \mathrm{nM}$ specific primers (Invitrogen by Life Technologies) (Supplementary Table 4) and $5 \mu \mathrm{L}$ of cDNA diluted 1:5 in water for a total volume of $20 \mu \mathrm{L}$. The samples were set up in duplicate on the same plate according to the following procedure: after an incubation of $2 \mathrm{~min}$ at $50^{\circ} \mathrm{C}$ and a denaturation step of $10 \mathrm{~min}$ at $95^{\circ} \mathrm{C}$, samples were subjected to $40 \mathrm{PCR}$ cycles $\left(30 \mathrm{~s}\right.$ at $95^{\circ} \mathrm{C}, 30 \mathrm{~s}$ at $60^{\circ} \mathrm{C}, 30 \mathrm{~s}$ at $72^{\circ} \mathrm{C}$ ). The mRNA expression levels were standardised using three reference genes (ACTB, EEF1A1 and $G A P D H)$. These three housekeeping genes showed expression changes among the different conditions studied. Therefore, the data were normalised to the geometric mean of ACTB, EEF1A1 and GAPDH (the most stable combination) following a report that suggests the geometric mean of multiple housekeeping genes is an accurate normalisation factor (Vandesompele et al. 2002). For each gene, the relative abundance of transcripts was determined by calculating $\mathrm{e}^{-\mathrm{ct}}$. The relative expression of the gene of interest was then related to the geometric mean of the relative expression of the reference genes.

\section{Statistical analysis}

The results are represented as mean \pm S.E.M., with a level of significance less than $0.05\left({ }^{*} P<0.05\right)$. An analysis of variance using repeated measurements (Proc.Mix procedure) was used to compare the average numbers of normal, soft, broken and double eggs among the different chicken groups over time. An analysis of variance (Proc.GLM procedure) was used to compare the average concentrations of secreted progesterone and levels of expression of adipokines and their receptors among the different groups. A chi-square test was used for analysis of percentage fertility between the different parameters. A Pearson test was used to analyse correlations between ovarian or plasma adipokine expression and reproductive parameters. The correlation was noted ' $r$ ' and the $P$ value was considered significant if $P<0.05$. SAS software (version 9.3, Cary, USA) was used for all analyses. Different letters indicate significant differences $(P<0.05)$.

\section{Results}

\section{Effect of restricted diet and fish oil supplementation on the egg production curve and on the amount and quality of eggs laid}

As shown in Fig. 1A, a delay by one week of entry into sexual maturity was observed in the Rt hens (24th week) compared with the Ad hens (23rd week). Similarly, we noted an earlier laying peak in the Ad hens (27th week) compared with the Rt hens (29th week). This can be explained by a delay in ovarian follicle maturation as shown in Fig. 1B. Fish oil supplementation postponed the laying peak of Rt hens (30th week) by one week but had no effect on the beginning of laying. Overall, Rt hens laid significantly fewer eggs than Ad hens (Table 1). This difference was notable from the 23rd to 27th week; thereafter, the number of laying eggs was unaffected by the diet except in the 31st week in which we observed the opposite trend (Fig. 1A). Although the number of eggs laid was fewer in Rt hens, their quality was better. Among the eggs laid by Rt hens, fewer were broken and soft and there were fewer double egg yolks (Table 1). In addition, we noted that the weight of the egg yolk, albumen and consequently the total weight, as well as the length and width of the eggs were reduced in Rt hens (Table 1). On the other hand, the proportion of shell and the static rigidity were increased and the dynamic rigidity decreased in Rt hens compared with Ad hens.
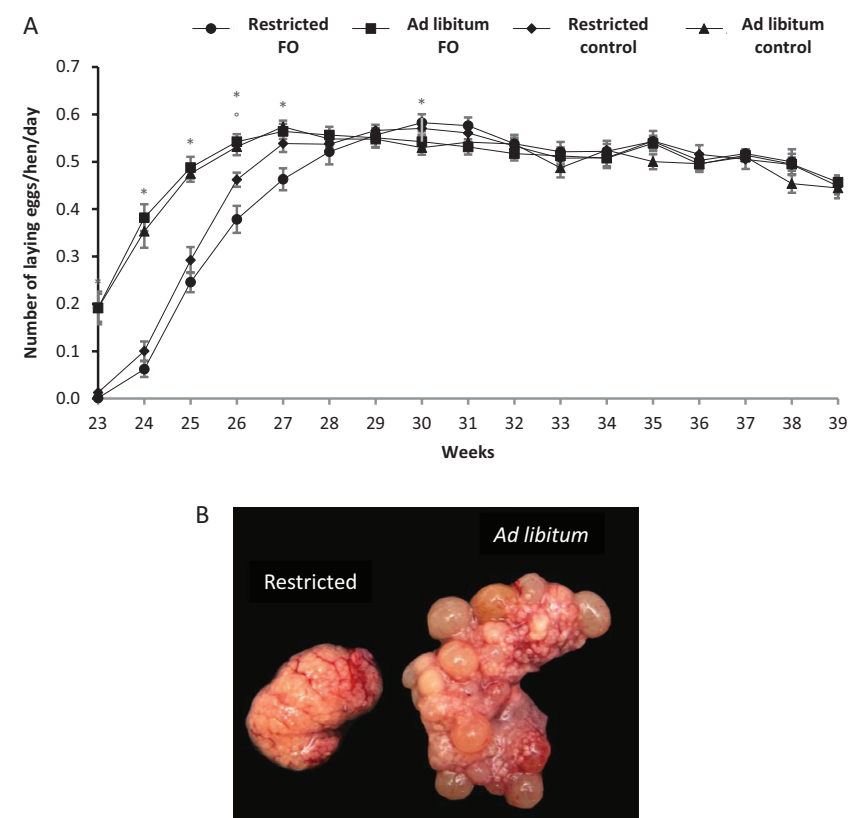

Figure 1 Laying curve (profile) (A) and representation of ovary (B) of broiler hens fed ad libitum or with a restricted diet either with (FO) or without (control) fish oil supplementation. (A) Eggs were collected daily for all hens ( $n=80$ for each group). (B) Representation of ovary of 21-week-old restricted (left side) or ad libitum (right side) hens. Results are presented as Ismeans \pm S.E.M. $* P<0.05$ (diet effect) and ${ }^{\circ} P<0.05$ (fish oil supplementation effect). 
Table 1 Number (23-39th week) and quality (25th week) by pen of laying eggs of broiler hens fed with ad libitum or restricted diet either with (FO) or without (control) fish oil supplementation.

\begin{tabular}{|c|c|c|c|c|c|c|c|}
\hline \multirow[b]{2}{*}{ Egg quality } & \multicolumn{2}{|c|}{ Ad libitum diet } & \multicolumn{2}{|c|}{ Restricted diet } & \multicolumn{3}{|c|}{$P$ value } \\
\hline & Control $(n=80)$ & $\mathrm{FO}(n=80)$ & Control $(n=80)$ & $\mathrm{FO}(n=80)$ & Diet & Supp & Diet*Supp \\
\hline Total laying eggs & $765 \pm 37$ & $744 \pm 27$ & $-705 \pm 38$ & $664 \pm 36$ & 0.04 & 0.35 & 0.76 \\
\hline Normal laying eggs & $727 \pm 38$ & $709 \pm 27$ & $692 \pm 37$ & $651 \pm 36$ & 0.16 & 0.36 & 0.72 \\
\hline Broken laying eggs & $14 \pm 3$ & $12 \pm 2$ & $6 \pm 1$ & $8 \pm 1$ & 0.001 & 0.96 & 0.20 \\
\hline Soft laying eggs & $4 \pm 0$ & $4 \pm 1$ & $2 \pm 0$ & $2 \pm 1$ & $<0.0001$ & 0.97 & 0.97 \\
\hline Double laying eggs & $19 \pm 2$ & $19 \pm 1$ & $6 \pm 2^{b}$ & $6 \pm 2$ & 0.03 & 0.96 & 0.84 \\
\hline Weight total egg (g) & $71.9 \pm 0.7$ & $69.4 \pm 0.8$ & $67.3 \pm 0.5$ & $67.0 \pm 0.6$ & $<0.0001$ & 0.03 & 0.10 \\
\hline Weight of egg yolk (g) & $14.7 \pm 0.2$ & $14.6 \pm 0.2$ & $14.0 \pm 0.2$ & $13.4 \pm 0.3$ & $<0.0001$ & 0.14 & 0.27 \\
\hline Weight of albumen (g) & $35.9 \pm 0.6$ & $35.9 \pm 0.6$ & $33.1 \pm 0.5$ & $32.9 \pm 0.5$ & $<0.0001$ & 0.80 & 0.85 \\
\hline Lenght $(\mathrm{mm})$ & $60.3 \pm 0.3$ & $59.3 \pm 0.3$ & $58.3 \pm 0.3$ & $58.2 \pm 0.3$ & $<0.0001$ & 0.07 & 0.17 \\
\hline Width (mm) & $45.9 \pm 0.2$ & $45.2 \pm 0.2$ & $44.7 \pm 0.1$ & $44.6 \pm 0.2$ & $<0.0001$ & 0.004 & 0.09 \\
\hline$\%$ of shell & $9.2 \pm 0.1$ & $9.2 \pm 0.1$ & $9.6 \pm 0.1$ & $9.5 \pm 0.1$ & 0.002 & 0.83 & 0.79 \\
\hline Static rigidity of shell & $145.7 \pm 4.0$ & $151.8 \pm 3.9$ & $156.3 \pm 4.0$ & $166.6 \pm 3.6$ & 0.001 & 0.04 & 0.59 \\
\hline Dynamic rigidity of shell & $143943 \pm 411$ & $141089 \pm 346$ & $127839 \pm 264$ & $132797 \pm 337$ & 0.0004 & 0.76 & 0.25 \\
\hline
\end{tabular}

Results are presented as Ismeans \pm S.E.M. $P$ values of the effects of diet, supplementation and the interaction between diet and supplementation were considered as significant if $P \leq 0.05$ (bold).

Supp, supplementation.

The fish oil supplementation decreased the total weight of the eggs and their width, while improving their static rigidity (Table 1 ).

\section{Effect of restricted diet and fish oil supplementation on number and weight of follicles}

The Rt diet significantly decreased the mean number of preovulatory follicles (Fig. 2A) as well as the weight of the preovulatory follicle 1 (F1) (Fig. 2B) and 2 (F2) (Fig. 2C), but did not affect the weight of the preovulatory follicle 3 (F3) (Fig. 2D) at the 39th week. The fish oil supplementation had no effect on these parameters.

\section{Effect of restricted diet and fish oil supplementation on fertility}

After the first artificial insemination (Al) at 27 weeks the Rt diet significantly decreased the percentage of unfertilised eggs (Table 2) and consequently improved the percentage fertility and hatchability of incubated eggs (Table 2). On the other hand, we noticed that the fish oil supplementation decreased the number of unfertilised eggs without altering the percentage fertility and hatchability (Table 2). Neither the Rt diet nor fish oil supplementation affected the percentage EEM, LEM and hatchability of fertile eggs (Table 2). We found similar results for the second Al (32 weeks) except that the percentage EEM decreased in Rt hens (data not shown).

\section{Effect of restricted diet and fish oil supplementation on in vitro steroidogenesis in hen primary granulosa cells}

As shown in Fig. 3, the production of progesterone (Fig. 3A), oestradiol (Fig. 3B), androstenedione (Fig. 3C) and testosterone (Fig. 3D) was significantly greater in the egg yolks of Rt hens than in Ad hens. In addition, the fish oil supplementation increased the production of progesterone (Fig. 3A) but had no effect on the production of oestradiol (Fig. 3B), androstenedione (Fig. 3C) or testosterone (Fig. 3D) in the egg yolks. As was the case for egg yolks, the Rt diet significantly increased the production of progesterone by granulosa cells stimulated or unstimulated with IGF1 $\left(10^{-8} \mathrm{M}\right)$ or $\mathrm{LH}\left(10^{-8} \mathrm{M}\right)$. Additionally, the fish oil supplementation increased progesterone production by Rt and Ad hen granulosa cells (Fig. 3E).
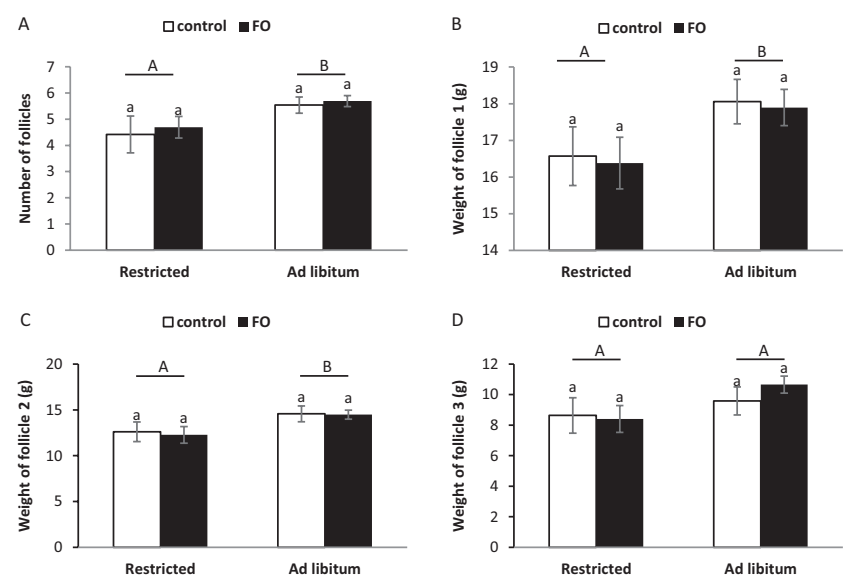

Figure 2 Mean number of follicles (A) and weight of preovulatory follicles 1 (B), 2 (C) and 3 (D) of broiler hens fed ad libitum or with a restricted diet either with (FO) or without (control) fish oil supplementation. Follicular hierarchy of 13 animals selected randomly from each group was analysed at the 39th week and each preovulatory follicle from each animal was weighed. Results are presented as Ismeans \pm S.E.M. Different letters indicate significant differences $P<0.05$. Capital letters indicate a significant effect of the diet, and lower-case letters indicate a significant effect of fish oil supplementation. 
Table 2 Percentage of unfertilised eggs, early (EEM) and late (LEM) embryonic mortality and fertility after first artificial insemination in broiler hens fed with ad libitum or restricted diet either with (FO) or without (control) $\omega 3$ PUFA supplementation.

\begin{tabular}{|c|c|c|c|c|c|c|}
\hline & \multicolumn{2}{|c|}{ Ad libitum diet } & \multicolumn{2}{|c|}{ Restricted diet } & \multicolumn{2}{|l|}{$P$ value } \\
\hline & Control $(n=80)$ & $\mathrm{FO}(n=80)$ & Control $(n=80)$ & $\mathrm{FO}(n=80)$ & Diet & Supp \\
\hline$\%$ Unfertilised & $17.60 \pm 1.01$ & $14.55 \pm 1.2$ & $10.49 \pm 1.65$ & $7.84 \pm 1.71$ & $<0.0001$ & 0.05 \\
\hline$\%$ EEM & $8.63 \pm 1.09$ & $6.69 \pm 1.54$ & $6.75 \pm 1.52$ & $6.68 \pm 0.95$ & 0.24 & 0.35 \\
\hline$\%$ LEM & $0.82 \pm 0.33$ & $1.49 \pm 0.51$ & $1.55 \pm 0.57$ & $2.22 \pm 0.66$ & 0.22 & 0.11 \\
\hline$\%$ Fertility & $74.15 \pm 0.95$ & $77.65 \pm 1.45$ & $83.88 \pm 2.29$ & $85.53 \pm 0.82$ & 0.05 & 0.63 \\
\hline$\%$ Hatchability of incubated eggs & $67.82 \pm 1.45$ & $73.08 \pm 1.27$ & $78.56 \pm 2.85$ & $80.78 \pm 1.84$ & 0.02 & 0.46 \\
\hline$\%$ Hatchability of fertile eggs & $90.92 \pm 1.83$ & $93.15 \pm 0.83$ & $95.43 \pm 0.99$ & $96.08 \pm 0.74$ & 0.5 & 0.84 \\
\hline
\end{tabular}

Results are presented as Ismeans \pm S.E.M. $P$ values of the effects of diet, supplementation and the interaction between diet and supplementation were considered as significant if $P \leq 0.05$ (bold).

EEM, early embryonic mortality; LEM, late embryonic mortality; Supp: supplementation.

\section{Effect of restricted diet and fish oil supplementation on plasma adipokine concentrations (RARRES2, ADIPOQ and NAMPT) during laying and association with fertility parameters}

From 21 to 39 weeks, we observed a weak effect on plasma ADIPOQ, RARRES2 and NAMPT concentrations (Table 3). Plasma ADIPOQ and NAMPT concentrations increased gradually, whereas plasma RARRES2 concentrations decreased progressively. We also noted a significant effect of diet only on plasma RARRES2 concentrations. More precisely, these effects appeared at the 21st week with greater concentrations in Rt hens than in Ad hens (Table 3). No effect of fish oil supplementation was observed on plasma adipokine concentrations. On the other hand, we showed that plasma RARRES2 levels were negatively correlated with the percentage hatchability of fertile eggs (number of hatched chicks/number of fertile eggs after 14 days of incubation) after the first Al and that plasma NAMPT levels were positively correlated with the mean number of follicles (Table 4).

\section{Effect of restricted diet and fish oil supplementation on the expression of adipokines in granulosa and theca cells, and association with the weight of ovarian follicles and in vitro progesterone production}

In granulosa and theca cells from F1 and F3, we detected the presence of the messenger RNA of all of the adipokines (ADIPOQ, RARRES2, NAMPT) and their receptors (ADIPOR1, ADIPOR2, CMKLR1 and CCRL2), as well as free fatty acid receptors (FFAR4). In theca cells from F1 (Table 5), the Rt diet decreased the expression of RARRES2 and increased the expression of ADIPOR2. In addition, fish oil supplementation increased the expression of NAMPT, CMKLR1 and FFAR4, whereas it decreased expression of ADIPOR1 and ADIPOR2. In theca cells from F3 (Table 5), the Rt diet decreased the expression of RARRES2, NAMPT and ADIPOR1; however, fish oil supplementation decreased the expression of RARRES2, ADIPOR1 and $A D I P O R 2$. In granulosa cells of F1 (data not shown), the Rt diet increased the expression of CCRL2, whereas the fish oil supplementation had no effect. Furthermore, we showed that in F1, the weight of the follicle was positively correlated with the expression of RARRES2 in granulosa cells and that the production of progesterone by primary F1 granulosa cells was negatively correlated with the expression of RARRES2 in theca cells (Table 6). Similarly, the weight of the follicle in F3 was positively
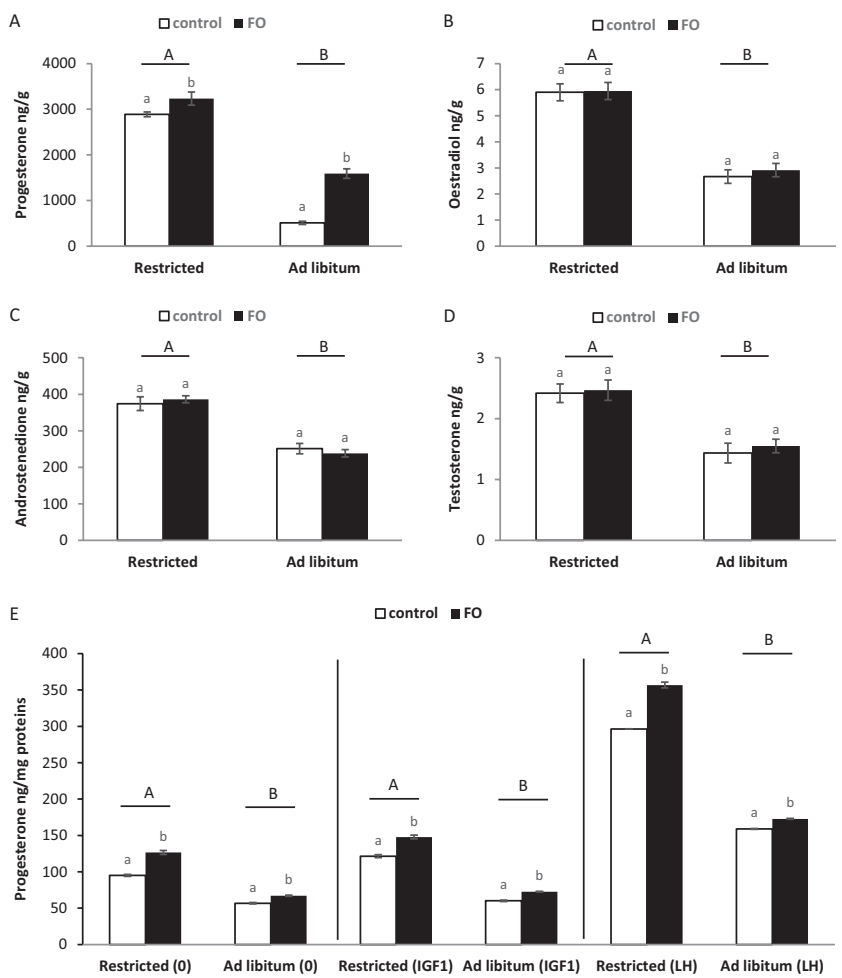

Figure 3 Levels of progesterone (A), oestradiol (B), androstenedione (C) and testosterone (D) in egg yolk and production of progesterone by granulosa cells ( $\mathrm{E}$ ) of broiler hens fed ad libitum or with a restricted diet either with (FO) or without (control) fish oil supplementation. Granulosa cells from preovulatory follicles 1 (F1) were seeded for $24 \mathrm{~h}$ and after overnight serum starvation, granulosa cells were incubated with IGF1 $\left(10^{-8} \mathrm{M}\right)$, or LH $\left(10^{-8} \mathrm{M}\right)$ for $48 \mathrm{~h}$. The culture medium was then collected and progesterone levels were determined. Hormone levels were assessed by ELISA at 39 weeks. Results are presented as Ismeans \pm S.E.M. Different letters indicate significant differences $P<0.05$. Capital letters indicate a significant effect of the diet and lower-case letters indicate a significant effect of fish oil supplementation. 
Table 3 Plasma ADIPOQ, RARRES2 and NAMPT concentrations of broiler hens fed with ad libitum or restricted diet either with (FO) or without (control) fish oil supplementation.

\begin{tabular}{|c|c|c|c|c|c|c|c|}
\hline & \multirow[b]{2}{*}{ Diet } & \multirow[b]{2}{*}{ Supp } & \multicolumn{5}{|c|}{ Weeks } \\
\hline & & & $21-39$ & 21 & 27 & 32 & 39 \\
\hline \multirow[t]{5}{*}{ ADIPOQ ( $\mu \mathrm{g} / \mathrm{mL})$} & Ad libitum & Control $(n=8)$ & $2.76 \pm 0.15$ & $2.7 \pm 0.1$ & $1.9 \pm 0.2$ & $3.0 \pm 0.3$ & $3.4 \pm 0.4$ \\
\hline & & $\mathrm{FO}(n=8)$ & $2.70 \pm 0.10$ & $2.7 \pm 0.1$ & $2.2 \pm 0.2$ & $2.8 \pm 0.2$ & $3.2 \pm 0.2$ \\
\hline & Restricted & Control $(n=8)$ & $2.80 \pm 0.12$ & $2.8 \pm 0.1$ & $2.3 \pm 0.3$ & $2.9 \pm 0.2$ & $3.3 \pm 0.2$ \\
\hline & & $\mathrm{FO}(n=8)$ & $2.70 \pm 0.09$ & $2.7 \pm 0.1$ & $2.6 \pm 0.2$ & $2.5 \pm 0.2$ & $3.1 \pm 0.2$ \\
\hline & $P$ value (week) & & $<0.0001$ & & & & \\
\hline \multirow[t]{5}{*}{ NAMPT (ng/mL) } & Ad libitum & Control $(n=8)$ & $158.63 \pm 6.54$ & $155.7 \pm 10.9$ & $127.8 \pm 6.1$ & $159.5 \pm 8.7$ & $196.3 \pm 16.0$ \\
\hline & & $\mathrm{FO}(n=8)$ & $156.84 \pm 7.05$ & $136.7 \pm 8.0$ & $140.0 \pm 12.6$ & $160.9 \pm 12.6$ & $189.8 \pm 18.2$ \\
\hline & Restricted & Control $(n=8)$ & $167.90 \pm 5.85$ & $148.5 \pm 7.7$ & $152.2 \pm 10.0$ & $180.5 \pm 11.9$ & $190.4 \pm 13.5$ \\
\hline & & $\mathrm{FO}(n=8)$ & $162.28 \pm 6.57$ & $145.0 \pm 10.2$ & $138.2 \pm 4.3$ & $152.6 \pm 9.5$ & $213.3 \pm 8.9$ \\
\hline & $P$ value (week) & & $<0.0001$ & & & & \\
\hline \multirow[t]{4}{*}{ RARRES2 (ng/mL) } & Ad libitum & Control $(n=8)$ & $218.66 \pm 5.95^{\mathrm{a}}$ & $184 \pm 8^{b}$ & $251 \pm 14$ & $224 \pm 6$ & $216 \pm 7$ \\
\hline & & $\mathrm{FO}(n=8)$ & $239.47 \pm 6.93^{\mathrm{a}, \mathrm{b}}$ & $264 \pm 11^{\mathrm{a}}$ & $239 \pm 9$ & $249 \pm 12$ & $206 \pm 17$ \\
\hline & Restricted & Control $(n=8)$ & $268.53 \pm 11.89^{c}$ & $286 \pm 6^{\mathrm{a}}$ & $275 \pm 27$ & $283 \pm 37$ & $230 \pm 20$ \\
\hline & & $\mathrm{FO}(n=8)$ & $244.20 \pm 6.49^{\mathrm{a}}$ & $282 \pm 6^{\mathrm{a}}$ & $252 \pm 17$ & $248 \pm 12$ & $205 \pm 6$ \\
\hline \multicolumn{8}{|l|}{$P$ value } \\
\hline & Week & 0.002 & & & & & \\
\hline & Diet & 0.001 & $<.0001$ & ns & ns & ns & \\
\hline & Supp & ns & $<.0001$ & ns & ns & $\mathrm{ns}$ & \\
\hline & Diet*Supp & 0.007 & $<.0001$ & $\mathrm{~ns}$ & $\mathrm{~ns}$ & $\mathrm{~ns}$ & \\
\hline
\end{tabular}

Results are presented as Ismeans \pm S.E.M. $P$ values of the effects of week, diet, supplementation and the interaction between diet and supplementation were considered as significant if $P \leq 0.05$ (bold). Different letters indicate significant differences when there is a significant interaction between diet and supplementation effect.

ns, non-significant; Supp, supplementation.

correlated with the expression of $A D I P O Q$ in granulosa cells (Table 6).

\section{Discussion}

In the present study, we showed that feed restriction improved the egg quality, fertility and hatchability of incubated eggs in broiler breeder hens. These effects were associated with higher steroid levels in egg yolk in vivo and with greater progesterone secretion by cultured granulosa cells. In addition, we showed for the first time that the plasma concentrations of the three adipokines, ADIPOQ, NAMPT and RARRES2 were variable during the laying period but only plasma RARRES2 concentration was increased by the feed restriction, being negatively correlated with the hatchability of fertile eggs. However, the effects of fish oil supplementation were less pronounced, since they were significant only on the eggshell rigidity, the percentage of unfertilised eggs and the amount of progesterone produced in vivo and in vitro.

In the present study, we found that the plasma RARRES2 concentration was increased, whereas plasma ADIPOQ and NAMPT concentrations were decreased during the laying period. For RARRES2, but not for ADIPOQ and NAMPT, these results are in good agreement with those already described in turkeys (Diot 2015), suggesting a species-dependent regulation of plasma ADIPOQ and NAMPT concentrations. In addition, we found that the plasma ADIPOQ and NAMPT profiles were negatively correlated with the number of eggs laid $(r=-0.5$, $P<0.0001$ and $r=-0.28, P<0.03$, respectively) between 27 and 39 weeks, whereas the opposite was observed for plasma RARRES2 ( $r=0.29, P<0.03$, data not shown). We also showed that adipokine amounts in plasma and/ or in ovarian cells were correlated with some fertility parameters. Indeed, we showed that plasma RARRES2 was negatively associated with the ratio of hatched

Table 4 Pearson correlation coefficient ( $r$ ) calculated between plasma adipokines (RARRES2, NAMPT) concentration and hatchability of fertile eggs after first artificial insemination (AI1) or number of follicles (39 weeks) of broiler hens fed with ad libitum or restricted diet either with or without fish oil supplementation.

\begin{tabular}{|c|c|c|}
\hline & Hatchability of fertile eggs Al1 ( $n=80$ per group) & Number of follicles ( $n=13$ per group) \\
\hline \multicolumn{3}{|c|}{ RARRES2 ( $n=8$ per group) } \\
\hline$r$ & -0.47 & \\
\hline$P$ value & 0.04 & \\
\hline \multicolumn{3}{|c|}{ NAMPT ( $n=8$ per group) } \\
\hline$r$ & & 0.35 \\
\hline$P$ value & & 0.05 \\
\hline
\end{tabular}

Values of $r$ and significance of the correlations are indicated. Correlations were considered as significant if $P \leq 0.05$ (bold). 


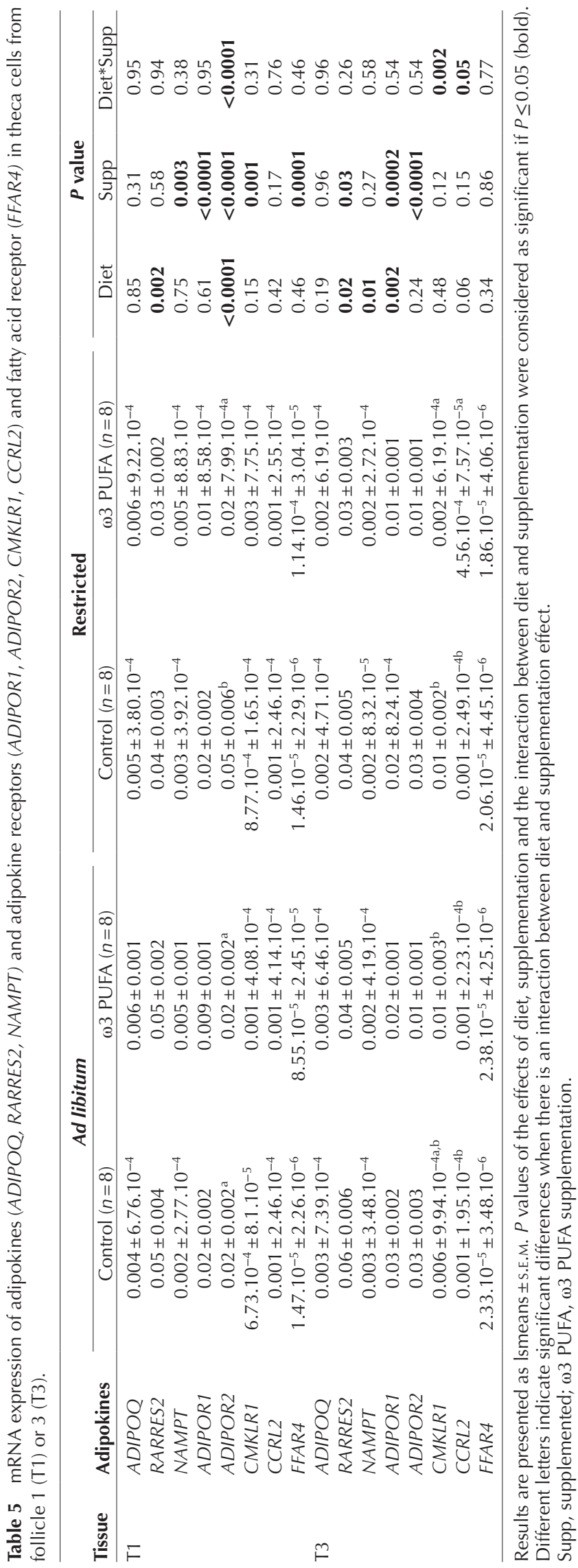

chicks/fertile eggs after 14 days of incubation after the first Al. Regarding to this data, RARRES2 could be used as a biomarker by breeding companies to select feed-restricted breeder hens with better fertility and hatchability but it might be confirmed using more animals. RARRES2 expression in theca cells was also negatively correlated with progesterone secretion by in vitro granulosa cells from $\mathrm{F} 1$. In avian species, only one paper has described the presence of RARRES2 in ovarian cells of turkey (Diot et al. 2015b), whereas ADIPOQ and NAMPT expression in the female reproductive tract has been already reported in the literature (Maddineni et al. 2005, Chabrolle et al. 2007, Ons et al. 2010, Diot et al. 2015a). In mammals, a negative association between RARRES2 and fertility has already been described. For example, treatment with recombinant human RARRES2 decreases in vitro granulosa cell steroidogenesis in human and bovine species (Reverchon et al. 2012, 2014) and inhibits in vitro bovine oocyte maturation (Reverchon et al. 2014). We observed that the plasma RARRES2 concentration is significantly higher in Rt hens that are leaner than Ad hens. This regulation is opposite to that described in obese humans. Current data show that plasma RARRES2 levels are reduced after prolonged fasting (van Herpen et al. 2013) and they are higher in obese patients compared with lean controls (Chang et al. 2016). Furthermore, in contrast to both animal models (Flachs et al. 2006, Neschen et al. 2006) and humans (Guebre-Egziabher et al. 2008), a $\omega 3$ PUFA-enriched diet did not affect plasma ADIPOQ levels in hens, suggesting different metabolic regulation in avian species.

In a good agreement with our data, previous studies have shown that egg performance (amount and quality) and fertility can be altered in overweight broiler breeder hens (Hocking et al. 1989, Fattori et al. 1991, Heck et al. 2004, Decuypere et al. 2010). We also observed that feed restriction reduced egg weight, more specifically yolk weight, probably due to a reduction in the F1 and F2 weights. Heck et al. (2004) also reported that egg abnormalities and weight were significantly reduced in restricted broiler breeder animals. Fertility parameters were also affected by the nutritional status. Our findings showed that the feed restriction decreased the percentage of unfertilised (assumed infertile) eggs, but it did not affect the embryo mortality (early or late) after the first AI. Hens fed excessively have previously been found to have lower percentages of fertile eggs, hatchability and embryonic viability (Yu et al. 1992). Herein, we have shown that the steroid concentrations in egg yolk (progesterone, oestradiol, androstenedione and testosterone) were higher in Rt hens. In hens and other bird species, considerably higher amounts of progesterone than of testosterone or androstenedione have been found around the germinal disc (the outer layer of the yolk) (Hackl et al. 2003). Progesterone is the precursor of androgens and oestrogens and is produced by the granulosa cells of the preovulatory follicles 
Table 6 Pearson correlation coefficient $(r)$ calculated between granulosa (from follicle 1, G1 or 3, G3) or theca (from follicle 1, T1) cells adipokines (ADIPOQ, RARRES2 and NAMPT) mRNA expression and weight of follicle (1 or 3) or granulosa from follicle 1 progesterone production (G1) of broiler hens fed with ad libitum or restricted diet either with or without fish oil supplementation.

\begin{tabular}{|c|c|c|c|c|}
\hline Tissue & & $\begin{array}{l}\text { Weight of follicle } \mathbf{1} \\
(n=13 \text { per group) }\end{array}$ & $\begin{array}{l}\text { Progesterone }(\mathrm{G} 1) \\
(\mathrm{n}=3 \text { per group) }\end{array}$ & $\begin{array}{l}\text { Weight of follicle } 3 \\
\text { ( } \mathrm{n}=13 \text { per group) }\end{array}$ \\
\hline \multirow[t]{3}{*}{ G1 } & RARRES2, ( $\mathrm{n}=8$ per group) & & & \\
\hline & r & 0.50 & & \\
\hline & $P$-value & 0.007 & & \\
\hline \multirow[t]{3}{*}{ T1 } & RARRES2, ( $\mathrm{n}=8$ per group) & & & \\
\hline & $r$ & & -0.55 & \\
\hline & $P$-value & & 0.001 & \\
\hline \multirow[t]{3}{*}{ G3 } & ADIPOQ, ( $n=8$ per group) & & & \\
\hline & $r$ & & & 0.47 \\
\hline & $P$-value & & & 0.02 \\
\hline
\end{tabular}

Values of $r$ and significance of the correlations are indicated. Correlations were considered as significant if $P \leq 0.05$.

(Huang \& Nalbandov 1979). We have also showed that granulosa cells from F1 produced more progesterone in Rt hens, probably leading to higher progesterone levels in egg yolks. In birds, progesterone produced by the F1 follicle is capable of triggering the LH preovulatory surge and ovulation (Scanes et al. 1977, Johnson \& van Tienhoven 1980). Thus, progesterone plays a key role in the control of fertility in hens. In our study, the percentage of unfertilised eggs was lower in Rt hens compared with Ad hens. This improved fertility can probably be explained by higher levels of progesterone in the egg yolks of restricted hens.

PUFAs have a great impact on reproduction, affecting prostaglandin (PG) synthesis, steroidogenesis, transcription factors and membrane properties in mammals and in chicken (Wathes et al. 2007). They act via cell surface and intracellular receptors/sensors that control cell signalling and gene expression patterns. Some effects of PUFAs appear to be mediated by, or at least associated with, changes in the fatty acid composition of cell membranes. In birds, many studies have shown that diets containing fish oil components such as EPA and DHA that are especially abundant in fish and can also be derived from alpha linolenic acid of linseed oil (Nettleton 1991) significantly increase sperm mobility (Kelso et al. 1997, Zanini et al. 2003). In hens, the main energy source for the developing chick embryo is supplied by fats in the egg yolk. Alteration of the egg yolk fatty acid profile could therefore be detrimental to the growth and development of the embryo during the incubation period (Leone et al. 2009). However, some nutritional studies performed in males (Cerolini et al. 2006) have reported that fish oil supplementation may be beneficial in reducing embryonic losses during incubation. In our study, we showed that a fish oilenriched diet in broiler breeder hens improved the percentage fertilisation but did not affect the percentage fertility or hatchability, or the level of embryo mortality (early or late). The supplementation level in fish oil ( $1 \%$ of the total diet) used in our study was probably not sufficient to detect a significant effect on fertility. In our experiment, although the lipids in the egg yolk were enriched with fish oil (data not shown), we observed no effect on the number of eggs. Although many authors have not reported any effect of fish oil supplementation on egg production (Baucells et al. 2000, Novak \& Scheideler 2001), others (Scheideler \& Froning 1996, Aziza et al. 2013) have observed increased egg production after supplementation with fish oil, but also with linseed or camelina meal. However, in the present study, we noted a reduction in the weight of the eggs and of chicks at hatching (data not shown) in both Rt and Ad hens, as previously reported by van Elswyk et al. Aigueperse et al. and Koppenol et al. in experiments with diets containing 1.5-2\% fish oil (Van Elswyk 1997, Aigueperse et al. 2013, Koppenol et al. 2015). Furthermore, Scheideler and Froning (1996) showed that inclusion of linseed also led to a reduction in egg weight (Scheideler \& Froning 1996). Since egg yolk is primarily derived from hepatically synthesised VLDL and vitellogenin (Burley 1993), one hypothesis is that omega 3 PUFA decrease the secretion of VLDL from the liver resulting in fewer eggs laid and possibly smaller egg yolks. Notably, the expression of the main receptor of EPA and DHA (FFAR4) was demonstrated for the first time in chicken ovarian cells in our study, suggesting that the effect of fish oil supplementation on fertility parameters could be mediated by FFAR4.

In conclusion, feed restriction but not fish oil at $1 \%$ of the total diet improved fertility in broiler breeder hens, and this improvement was associated with an increase in progesterone production in vivo in egg yolk and in vitro by ovarian cells (granulosa). Moreover, we found that the three adipokines, ADIPOQ, NAMPT and RARRES2 are present in plasma and ovarian cells. However, only the plasma concentrations of RARRES2 were affected by diet throughout the laying period. Furthermore, plasma RARRES2 levels were negatively correlated with the percentage hatchability of fertile eggs. Further experiments are necessary to better understand the role 
of RARRES2 in the interactions between nutrition and reproduction in avian species.

\section{Supplementary data}

This is linked to the online version of the paper at https://doi.org/10.1530/REP-17-0678.

\section{Declaration of interest}

The authors declare that there is no conflict of interest that could be perceived as prejudicing the impartiality of the research reported.

\section{Funding}

The authors are grateful to the Région Centre Val de Loire for the supporting grants 'Adipofertikines' $N^{\circ} 32000407$ and 'PREVADI' No 32000820 and also to MENRT for the supporting grant for Namya Mellouk as a PhD student.

\section{References}

Aigueperse N, Calandreau L \& Bertin A 2013 Maternal diet influences offspring feeding behavior and fearfulness in the precocial chicken. PLoS ONE 8 e77583. (https://doi.org/10.1371/journal.pone.0077583)

Aziza AE, Quezada N \& Cherian G 2013 Nutrient digestibility, egg quality, and fatty acid composition of brown laying hens fed camelina or flaxseed meal. Journal of Applied Poultry Research 22 832-841. (https:// doi.org/10.3382/japr.2013-00735)

Bain M 1990 Eggshell Strength: A Mechanical/Ultrastructural Evaluation. $\mathrm{PhD}$ thesis. Faculty of Veterinary Medicine, University of Glasgow, UK

Baucells MD, Crespo N, Barroeta AC, Lopez-Ferrer S \& Grashorn MA 2000 Incorporation of different polyunsaturated fatty acids into eggs. Poultry Science 79 51-59. (https://doi.org/10.1093/ps/79.1.51)

Canepa SLA, Bluteau A, Fagu C, Flon C \& Monniaux D 2008 Validation d'une methode immunoenzymatique pour le dosage de la progesterone dans le plasma des ovins et des bovins. Les Cahiers Techniques de L'INRA 64 19-30.

Cerolini S, Zaniboni L, Maldjian A \& Gliozzi T 2006 Effect of docosahexaenoic acid and alpha-tocopherol enrichment in chicken sperm on semen quality, sperm lipid composition and susceptibility to peroxidation. Theriogenology 66 877-886. (https://doi.org/10.1016/j. theriogenology.2006.02.022)

Chabrolle C, Tosca L, Crochet S, Tesseraud S \& Dupont J 2007 Expression of adiponectin and its receptors (AdipoR1 and AdipoR2) in chicken ovary: potential role in ovarian steroidogenesis. Domestic Animal Endocrinology 33 480-487. (https://doi.org/10.1016/j.domaniend.2006.08.002)

Chang SS, Eisenberg D, Zhao L, Adams C, Leib R, Morser J \& Leung L 2016 Chemerin activation in human obesity. Obesity 24 1522-1529. (https:// doi.org/10.1002/oby.21534)

Chen SE, McMurtry JP \& Walzem RL 2006 Overfeeding-induced ovarian dysfunction in broiler breeder hens is associated with lipotoxicity. Poultry Science 85 70-81. (https://doi.org/10.1093/ps/85.1.70)

Chen CI, Hsu MI, Lin SH, Chang YC, Hsu CS \& Tzeng CR 2015 Adiponectin and leptin in overweight/obese and lean women with polycystic ovary syndrome. Gynecological Endocrinology 31 264-268. (https://doi.org/1 0.3109/09513590.2014.984676)

Cobb-Vantress 2008 Cobb 500 Breeder Management Guide. Cobb Edition pp 1-68.

Coucke P, Dewil E, Decuypere E \& De Baerdemaeker J 1999 Measuring the mechanical stiffness of an eggshell using resonant frequency analysis. British Poultry Science 40 227-232. (https://doi. org/10.1080/00071669987647)

de Luis DA, Pacheco D, Primo D, Izaola O \& Aller R 2017 The association of SNP276G $>$ T at adiponectin gene with insulin resistance and circulating adiponectin in morbid obese patients after a biliopancreatic diversion surgery. Obesity Surgery12 3247-3252. (https://doi.org/10.1007/ s11695-017-2766-7)

Decuypere E, Bruggeman V, Everaert N, Li Y, Boonen R, De Tavernier J, Janssens S \& Buys N 2010 The broiler breeder paradox: ethical, genetic and physiological perspectives, and suggestions for solutions. British Poultry Science 51 569-579. (https://doi.org/10.1080/00071668.2010. 519121)

Diot M, Reverchon M, Rame C, Baumard Y \& Dupont J 2015a Expression and effect of NAMPT (visfatin) on progesterone secretion in hen granulosa cells. Reproduction 150 53-63. (https://doi.org/10.1530/REP-15-0021)

Diot M, Reverchon M, Rame C, Froment P, Brillard JP, Briere S, Leveque G, Guillaume D \& Dupont J 2015b Expression of adiponectin, chemerin and visfatin in plasma and different tissues during a laying season in turkeys. Reproductive Biology and Endocrinology 13 81. (https://doi. org/10.1186/s12958-015-0081-5)

Dunn IC, Bain M, Edmond A, Wilson PW, Joseph N, Solomon S, De Ketelaere B, De Baerdemaeker J, Schmutz M, Preisinger R et al. 2005 Heritability and genetic correlation of measurements derived from acoustic resonance frequency analysis; a novel method of determining eggshell quality in domestic hens. British Poultry Science 46 280-286. (https://doi.org/10.1080/00071660500098574)

Farshchian F, Ramezani Tehrani F, Amirrasouli H, Rahimi Pour H, Hedayati M, Kazerouni F \& Soltani A 2014 Visfatin and resistin serum levels in normal-weight and obese women with polycystic ovary syndrome. International Journal of Endocrinology and Metabolism 12 e15503. (https://doi.org/10.5812/ijem.15503)

Fattori TR, Wilson HR, Harms RH \& Miles RD 1991 Response of broiler breeder females to feed restriction below recommended levels. 1 . Growth and reproductive performance. Poultry Science 70 26-36. (https://doi.org/10.3382/ps.0700026)

Flachs P, Mohamed-Ali V, Horakova O, Rossmeisl M, HosseinzadehAttar MJ, Hensler M, Ruzickova J \& Kopecky J 2006 Polyunsaturated fatty acids of marine origin induce adiponectin in mice fed a high-fat diet. Diabetologia 49 394-397. (https://doi.org/10.1007/s00125-0050053-y)

Guebre-Egziabher F, Rabasa-Lhoret R, Bonnet F, Bastard JP, Desage M, Skilton MR, Vidal H \& Laville $\mathbf{M} 2008$ Nutritional intervention to reduce the $n-6 / n-3$ fatty acid ratio increases adiponectin concentration and fatty acid oxidation in healthy subjects. European Journal of Clinical Nutrition 62 1287-1293. (https://doi.org/10.1038/sj.ejcn.1602857)

Guesdon V, Ahmed AM, Mallet S, Faure JM \& Nys Y 2006 Effects of beak trimming and cage design on laying hen performance and egg quality. British Poultry Science 47 1-12. (https://doi. org/10.1080/00071660500468124)

Hackl R, Bromundt V, Daisley J, Kotrschal K \& Mostl E 2003 Distribution and origin of steroid hormones in the yolk of Japanese quail eggs (Coturnix coturnix japonica). Journal of Comparative Physiology B 173 327-331. (https://doi.org/10.1007/s00360-003-0339-7)

Haider DG, Schindler K, Schaller G, Prager G, Wolzt M \& Ludvik B 2006 Increased plasma visfatin concentrations in morbidly obese subjects are reduced after gastric banding. Journal of Clinical Endocrinology and Metabolism 91 1578-1581. (https://doi.org/10.1210/jc.2005-2248)

Heck A, Onagbesan O, Tona K, Metayer S, Putterflam J, Jego Y, Trevidy JJ, Decuypere E, Williams J, Picard M et al. 2004 Effects of ad libitum feeding on performance of different strains of broiler breeders. British Poultry Science 45 695-703. (https://doi.org/10.1080/00071660400006537)

Hendricks GL 3rd, Hadley JA, Krzysik-Walker SM, Prabhu KS, VasilatosYounken R \& Ramachandran R 2009 Unique profile of chicken adiponectin, a predominantly heavy molecular weight multimer, and relationship to visceral adiposity. Endocrinology 150 3092-3100. (https://doi.org/10.1210/en.2008-1558)

Hocking PM 1993 Effects of body weight at sexual maturity and the degree and age of restriction during rearing on the ovarian follicular hierarchy of broiler breeder females. British Poultry Science 34 793-801. (https:// doi.org/10.1080/00071669308417638)

Hocking PM, Waddington D, Walker MA \& Gilbert AB 1989 Control of the development of the ovarian follicular hierarchy in broiler breeder pullets by food restriction during rearing. British Poultry Science 30 161-173. (https://doi.org/10.1080/00071668908417134)

Huang ES \& Nalbandov AV 1979 Steroidogenesis of chicken granulosa and theca cells: in vitro incubation system. Biology of Reproduction 20 442-453. (https://doi.org/10.1095/biolreprod20.3.442) 
Johnson AL \& van Tienhoven A 1980 Hypothalamo-hypophyseal sensitivity to hormones in the hen. I. Plasma concentrations of LH, progesterone, and testosterone in response to central injections of progesterone and R5020. Biology of Reproduction 23 910-917. (https://doi.org/10.1095/ biolreprod23.5.910)

Kasher-Meron M, Mazaki-Tovi S, Barhod E, Hemi R, Haas J, Gat I, Zilberberg E, Yinon Y, Karasik A \& Kanety H 2014 Chemerin concentrations in maternal and fetal compartments: implications for metabolic adaptations to normal human pregnancy. Journal of Perinatal Medicine 42 371-378. (https://doi.org/10.1515/jpm-2013-0166)

Kelso KA, Cerolini S, Noble RC, Sparks NH \& Speake BK 1997 The effects of dietary supplementation with docosahexaenoic acid on the phospholipid fatty acid composition of avian spermatozoa. Comparative Biochemistry and Physiology - Part B: Biochemistry and Molecular Biology 118 65-69.

Koppenol A, Delezie E, Wang Y, Franssens L, Willems E, Ampe B, Buyse J \& Everaert N 2015 Effects of maternal dietary EPA and DHA supplementation and breeder age on embryonic and post-hatch performance of broiler offspring: age and n-3 pufa affect embryonic and post-hatch performance. Journal of Animal Physiology and Animal Nutrition 99 (Supplement S1) 36-47. (https://doi.org/10.1111/jpn.12308)

Kort DH, Kostolias A, Sullivan C \& Lobo RA 2015 Chemerin as a marker of body fat and insulin resistance in women with polycystic ovary syndrome. Gynecological Endocrinology 31 152-155. (https://doi.org/1 $0.3109 / 09513590.2014 .968547)$

Krzysik-Walker SM, Ocon-Grove OM, Maddineni SR, Hendricks GL 3rd \& Ramachandran R 2008 Is visfatin an adipokine or myokine? Evidence for greater visfatin expression in skeletal muscle than visceral fat in chickens. Endocrinology 149 1543-1550. (https://doi.org/10.1210/en.2007-1301)

Leone VA, Stransky DL, Aydin R \& Cook ME 2009 Evidence for conjugated linoleic acid-induced embryonic mortality that is independent of egg storage conditions and changes in egg relative fatty acids. Poultry Science 88 1858-1868. (https://doi.org/10.3382/ps.2009-00157)

Li Z, Wang Y, Tian X, Shang P, Chen H, Kang X, Tian Y \& Han R 2017 Characterization of the visfatin gene and its expression pattern and effect on 3T3-L1 adipocyte differentiation in chickens. Gene 632 16-24. (https://doi.org/10.1016/j.gene.2017.08.025)

Maddineni S, Metzger S, Ocon O, Hendricks G 3rd \& Ramachandran R 2005 Adiponectin gene is expressed in multiple tissues in the chicken: food deprivation influences adiponectin messenger ribonucleic acid expression. Endocrinology 146 4250-4256. (https://doi.org/10.1210/ en.2005-0254)

Maillard V, Elis S, Desmarchais A, Hivelin C, Lardic L, Lomet D, Uzbekova S, Monget P \& Dupont J 2017 Visfatin and resistin in gonadotroph cells: expression, regulation of $\mathrm{LH}$ secretion and signalling pathways. Reproduction, Fertility and Development 12 2479-2495. (https://doi.org/10.1071/RD16301)

Malik NM, Carter ND, Murray JF, Scaramuzzi RJ, Wilson CA \& Stock MJ 2001 Leptin requirement for conception, implantation, and gestation in the mouse. Endocrinology 142 5198-5202. (https://doi.org/10.1210/ endo.142.12.8535)

Neschen S, Morino K, Rossbacher JC, Pongratz RL, Cline GW, Sono S, Gillum M \& Shulman GI 2006 Fish oil regulates adiponectin secretion by a peroxisome proliferator-activated receptor-gamma-dependent mechanism in mice. Diabetes 55 924-928. (https://doi.org/10.2337/ diabetes.55.04.06.db05-0985)

Nettleton JA 1991 Omega-3 fatty acids: comparison of plant and seafood sources in human nutrition. Journal of the American Dietetic Association $91331-337$.

Novak C \& Scheideler SE 2001 Long-term effects of feeding flaxseed-based diets. 1. Egg production parameters, components, and eggshell quality in two strains of laying hens. Poultry Science 80 1480-1489. (https://doi. org/10.1093/ps/80.10.1480)

Ons E, Gertler A, Buyse J, Lebihan-Duval E, Bordas A, Goddeeris B \& Dridi S 2010 Visfatin gene expression in chickens is sex and tissue dependent. Domestic Animal Endocrinology 38 63-74. (https://doi. org/10.1016/j.domaniend.2009.08.007)

Pitel F, Faraut T, Bruneau G \& Monget P 2010 Is there a leptin gene in the chicken genome? Lessons from phylogenetics, bioinformatics and genomics. General and Comparative Endocrinology 167 1-5. (https:// doi.org/10.1016/j.ygcen.2009.10.006)
Reverchon M, Cornuau M, Rame C, Guerif F, Royere D \& Dupont J 2012 Chemerin inhibits IGF-1-induced progesterone and estradiol secretion in human granulosa cells. Human Reproduction 27 1790-1800. (https:// doi.org/10.1093/humrep/des089)

Reverchon M, Bertoldo MJ, Rame C, Froment P \& Dupont J 2014 CHEMERIN (RARRES2) decreases in vitro granulosa cell steroidogenesis and blocks oocyte meiotic progression in bovine species. Biology of Reproduction 90 102. (https://doi.org/10.1095/biolreprod.113.117044)

Sauveur B 1988 Reproduction Des Volailles et Production d'oeufs. Institut national de la Recherche agronomique. pp 1-449 Editor: INRA, Paris 1988

Savory CJ \& Maros K 1993 Influence of degree of food restriction, age and time of day on behaviour of broiler breeder chickens. Behavioural Processes 29 179-189. (https://doi.org/10.1016/0376-6357(93)90122-8)

Scanes CG, Godden PM \& Sharp PJ 1977 An homologous radioimmunoassay for chicken follicle-stimulating hormone: observations on the ovulatory cycle. Journal of Endocrinology 73 473-481. (https://doi.org/10.1677/ joe.0.0730473)

Scheideler SE \& Froning GW 1996 The combined influence of dietary flaxseed variety, level, form, and storage conditions on egg production and composition among vitamin E-supplemented hens. Poultry Science 75 1221-1226. (https://doi.org/10.3382/ps.0751221)

Sirotkin AV \& Grossmann R 2015 Interrelationship between feeding level and the metabolic hormones leptin, ghrelin and obestatin in control of chicken egg laying and release of ovarian hormones. Comparative Biochemistry and Physiology Part A: Molecular and Integrative Physiology 184 1-5. (https://doi.org/10.1016/j.cbpa.2015.01.016)

Taouis M, Chen JW, Daviaud C, Dupont J, Derouet M \& Simon J 1998 Cloning the chicken leptin gene. Gene 208 239-242. (https://doi. org/10.1016/S0378-1119(97)00670-7)

Van Elswyk ME 1997 Comparison of n-3 fatty acid sources in laying hen rations for improvement of whole egg nutritional quality: a review. British Journal of Nutrition 78 (Supplement 1) S61-S69. (https://doi. org/10.1079/BJN19970135)

van Emous RA, Kwakkel RP, van Krimpen MM, van den Brand H \& Hendriks WH 2015 Effects of growth patterns and dietary protein levels during rearing of broiler breeders on fertility, hatchability, embryonic mortality, and offspring performance. Poultry Science 94 681-691. (https://doi.org/10.3382/ps/pev024)

van Herpen NA, Sell H, Eckel J, Schrauwen P \& Mensink RP 2013 Prolonged fasting and the effects on biomarkers of inflammation and on adipokines in healthy lean men. Hormone and Metabolic Research 45 378-382. (https://doi.org/10.1055/s-0032-1330015)

Vandesompele J, De Preter K, Pattyn F, Poppe B, Van Roy N, De Paepe A \& Speleman F 2002 Accurate normalization of real-time quantitative RT-PCR data by geometric averaging of multiple internal control genes. Genome Biology 3 RESEARCH0034.

Wathes DC, Abayasekara DR \& Aitken RJ 2007 Polyunsaturated fatty acids in male and female reproduction. Biology of Reproduction 77 190-201. (https://doi.org/10.1095/biolreprod.107.060558)

Yan J, Gan L, Chen D \& Sun C 2013 Adiponectin impairs chicken preadipocytes differentiation through p38 MAPK/ATF-2 and TOR/p70 S6 kinase pathways. PLOS ONE 8 e77716. (https://doi.org/10.1371/journal. pone.0077716)

Yu MW, Robinson FE, Charles RG \& Weingardt R 1992 Effect of feed allowance during rearing and breeding on female broiler breeders. 2 . Ovarian morphology and production. Poultry Science 71 1750-1761. (https://doi.org/10.3382/ps.0711750)

Zanini SF, Torres CA, Bragagnolo N, Turatti JM, Silva MG \& Zanini MS 2003 Evaluation of the ratio of omega(6: omega3 fatty acids and vitamin E levels in the diet on the reproductive performance of cockerels. Archiv für Tierernährung 57 429-442.

Received 6 November 2017

First decision 28 November 2018

Revised manuscript received 30 December 2018

Accepted 26 January 2018 